\title{
Model Pembelajaran Pendidikan Agama Islam Berlandaskan Multikultural (Telaah Implikasi Model Cooperative Learning di Perguruan Tinggi)
}

\author{
Rahmat \\ Institut Pesantren KH Abdul Chalim \\ rahmatpaikhac@gmail.com
}

Diterima: 02 Oktober 2019 | Direvisi: 29 Oktober 2019 | Disetujui: 03 November 2019

(C) 2018 Program Studi Pendidikan Agama Islam Fakultas Agama Islam Universitas Islam Malang

\begin{abstract}
The learning model of Islamic Education (PAI) in tertiary institutions has recently been highlighted by many observers of education. This situation is reasonable considering that from year to year, racism acts mainly occur in universities. A nation of caliber in Indonesia with large heterogeneity is indeed very possible for friction between students, considering all the possibilities, this paper tries to analyze the PAI learning model based on multiculturalism in tertiary institutions. This research uses the library research method by analyzing the results of the study of books and scientific journals. This research produces a multicultural PAI based learning model through which students can absorb and practice multicultural PAI based learning in tertiary institutions so that it has implications for attitudes of respect, acceptance and appreciation of differences between students.
\end{abstract}

Keywords: Learning Model, PAI Multicultural, Higher Education

\begin{abstract}
Abstrak
Model pembelajaran Pendidikan Agama Islam (PAI) di perguruan tinggi akhirakhir ini disoroti banyak pemerhati pendidikan. Keadaan ini merupakan hal wajar mengingat dari tahun ketahun terus terjadi perbuatan rasisme terutama di perguruan tingginya. Bangsa sekaliber Indonesia dengan heterogenitas besar memang sangat memungkinkan terjadinya gesekan antar mahasiswa, memperhatikan segala kemungkinan tersebut tulisan ini mencoba menganalisis model pembelajaran PAI berlandaskan multikultural di perguruan tinggi. Penelitian ini menggunakan metode library research dengan menganalisis hasil kajian buku dan jurnal ilmiah. Penelitian ini menghasilkan model pembelajaran PAI berlandaskan multikultural yang dengannya mahasiswa dapat menyerap dan mengamalkan pembelajaran PAI berlandaskan multikultural di perguruan tinggi sehingga berimplikasi pada sikap penghormatan, penerimaan dan penghargaan terhadap perbedaan antar mahasiswa.
\end{abstract}

Kata Kunci: Model Pembelajaran, PAI, Multikultural, Perguruan Tinggi 


\section{Pendahuluan}

Kemajemukan dalam tubuh bangsa kita Indonesia ialah anugerah dari Allah SWT yang perlu disyukuri oleh rakyatnya. Tercatat Indonesia memiliki beragam budaya, suku, 5 (lima) agama yang diakui, adat istiadat serta bahasa yang beraneka macam. Meskipun bangsa ini telah kebal dengan berbagai isu sara dan atau isu intoleran akan tetapi akhir-akhir ini kembali kedewasaan bangsa yang heterogen ini diuji dengan kejadian tindak rasisme yang menimpa saudara kita dari Papua yang dimana kejadian tersebut terjadi di Surabaya dan Malang, akibatnya bentrokan tidak terelakkan baik di kedua kota itu maupun di Papua sendiri ${ }^{1}$ yang berujung pada pulangnya puluhan bahkan ratusan mahasiswa ke daerah asal mereka yakni Papua.

Hal di atas sebenarnya tidak akan terjadi atau setidaknya dapat diminimalisir dengan cara memperbaiki model pembelajaran. Karena, model pembelajaran di perguruan tinggi saat ini meskipun telah diberikan kebebasan dalam menentukan arah pembelajaran (kurikulum) multikultural tersebut ${ }^{2}$ akan tetapi masih belum dapat memberikan dampak yang signifikan.

Secara hakiki, pembelajaran adalah sebuah interaksi belajar dan mengajar antara dosen dengan mahasiswanya, adakalanya interaksi secara langsung seperti kegiatan rutin tatap muka begitupun interaksi tidak langsung, yakni memanfaatkan media elektronik (media sosial). Model pembelajaran merupakan sebuah rancangan atau pola yang dapat dipakai untuk membuat kurikulum (rancangan pembelajaran jangka panjang), merencanakan materi pembelajaran, dan memberikan bimbingan pembelajaran di kelas atau di luarnya.

Pada dasarnya, gerakan multikulturalisme dan kajian tentang pendidikan multikultural mulai marak pada awal tahun 1960-an di Amerika Serikat. Hal itu sejalan dengan gerakan sipil kaum kulit hitam (black Amerika), dan etnik minoritas yang berasal dari berbagai negara di luar Amerika dan Eropa. Ada banyak tokoh dan sarjana yang turut serta dalam perjuangan untuk kesetaraan warga negara tersebut yang berasal dari berbagai bidang dan keahlian. Salah seorang sarjana dan tokoh yang hingga kini masih sangat telaten dalam menggarap tema-tema multikulturalisme dan pendidikan multikultural sejak dahulu di AS adalah James A. Banks,

\footnotetext{
${ }^{1}$ https://www.liputan6.com/news/read/4041466/khofifah-ucapan-ke-mahasiswa-papua-dimalang-bukan-mewakili-masyarakat-jatim diakses 19 Agustus 2019. Pukul 16.13 WIB.

${ }^{2}$ Sulalah, Pendidikan Multikultural Didaktika Nilai-nilai Universalitas Kebangsaan, (Malang: UIN-Maliki Press, 2011), hlm. 67.
} 
seorang warga kulit hitam yang mejadi guru besar pada Universitas Washington, Seattle, AS. Salah satu buku karyanya Handbook Of Research on Multicultural Education, setebal 882 halaman. ${ }^{3}$

Indonesia merupakan sebuah bangsa besar yang plural juga Multikultural. Sebagaimana di dalam sebuah penelitian tentang etnologis, kabarnya sekitaran 740 etnis, 400 bahasa, 6 agama dan 17 ribu pulau yang dimiliki oleh bangsa Indonesia. ${ }^{5}$ Multikulturalisme merupakan peristilahan yang menjelaskan suatu pandangan terkait keragaman hidup bangsa dunia, atau konsep kebudayaan yang mengharuskan pengakuan terhadap kenyataan adanya keanekaragaman, serta bermacam model kultur (Multikultur) yang terdapat didalam kehidupan rakyat bergantung pada value, politik kebiasaan, budaya serta sistem yang dianut. ${ }^{6}$

Multikulturalisme telah sering diperbincangkan dalam seminar maupun workshop. 7 Namun, belum sepenuhnya Indonesia sebagai pewaris multikulturalisme sadar akan hal tersebut. Memperhatikan kenyataan ini, maka sangat diperlukan upaya pendidikan, khususnya pendidikan agama Islam dalam memberikan arahan atau wawasan dan bimbingan terkait prilaku Multikultural.

Pendidikan adalah proses wajib yang harus dijalani oleh umat manusia. Begitu sangat pentingya sehingga Muhammad Alim berpendapat, pendidikan bagaikan jantung dan tuntunan bagi manusia. ${ }^{8}$ Sehingga, keadaan demikian pula berlaku pada pembelajaran pendidikan agama Islam (PAI) di kampus. Sebab PAI sebagai ikhtiar menambah pemahaman, pengamalan dan pembiasaan menjalankan agama pada diri mahasiswa. Dengan PAI, mahasiswa sadar budaya untuk berprilaku luhur serta terampil dalam pengamalan ilmunya berdasarkan nilai Islami. ${ }^{9}$

Sayangnya, harapan dari PAI belum mampu direalisasikan dan atau tidak mampu terlaksana secara optimal. Bahkan, ia semakin kehilangan

\footnotetext{
${ }^{3}$ James A. Banks and Cherry A. McGee Banks, Handbook of Research on Multicultural Education, (San Francisco, California: Jossey-Bass, 1996), hlm. xii.

${ }^{4}$ Atau tepatnya 1.340 suku bangsa menurut sensus BPS tahun 2010. Wikipedia diakses 01 Juni 2019, pukul 14.51 WIB.

${ }^{5}$ Suryadinata dkk, Penduduk Indonesia, (Jakarta: LP3ES, 2003), hlm. 102.

${ }^{6}$ Yaya Suryana, H. A. Rusdiana, Pendidikan Multikultural Suatu Upaya Penguatan Jati Diri Bangsa, "Konsep-Prinsip-Implementasi", (Bandung: Pustaka Setia, 2015), hlm. 100.

${ }^{7}$ Jurnal Imam Setyobudi dan Mukhals Alkaf, Kendala Multikulturalisme di Indonesia Analisis Diakronis dan Sinkronis, (Mudra Jurnal Seni Budaya) ISSN 0854-3461, Vol 26, No2 Juli 2011, hlm. 201.

${ }^{8}$ Muhammad Alim, Pendidikan Agama Islam Upaya Pembentukan Pemikiran dan Kepribadian Muslim (Bandung : PT.Remaja Rosda Karya, 2006), hlm.8.

${ }^{9}$ Zakiah Darajat, Pendidikan Islam dalam Keluarga dan Sekoalh, (Bandung: Remaja Rosdakarya, 1995), hlm. 35. Baca, Jalaluddin, Teologi Pendidikan, (Jakarta: RajaGrafindo, 2003), hlm. 91-101.
} 
perannya mengantarkan mahasiswa untuk berakhlak (bersikap menghargai perbedaan /keragaman), serta memahami dan mengamalkan ajaran agamanya. Kalau demikian kenyataanya, bukannya pelajaran atau matakuliah agama Islam memperbaiki sikap Multikultural, malah pelajaran PAI ini kelak tidak diminati lagi kemudian tersingkirkan dengan sendirinya. ${ }^{10}$

\section{Metode}

Penelitian ini memanfaatkan pendekatan Kualitatif Deskriptif, yang diawali dengan mencari informasi utama dan mendeskripsikannya, gambaran kummpulan data yang sistemic, penjabaran deskriptif tidak menggunakan angka. ${ }^{11}$ Adapun penelitian deskriptif itu suatu penelitian yang mendeskripsikan kenyataan lapangan, baik yang alamiah maupun hasil rekayasa manusia tersebut. ${ }^{12}$

Penelitian ini difokuskan kepada kajian pustaka (Library Research), yaitu suatu penelitian yang fokus pada pencarian data kepustakaan. ${ }^{13}$ Definisi lain untuk penelitian Livrary Research yakni sebuah penelitian yang menggali literatur seperti buku, jurnal ilmiah, majalah, koran, dokumen, dan lain sebagainya untuk mendapatkan data dan informasi lengkap. ${ }^{14}$

Penulis menggunakan penelitian ini berlandaskan pada pembahasan mengenai Model Pembelajaran Pendidikan Agama Islam Berlandaskan Multikultural (Telaah Implikasi Model Cooperative Learning di Perguruan Tinggi), penelitian tersebut lebih terarah pada penggunaan model pendekatan kajian isi (Content Analysis), yang mana merupakan aktivitas pembahasan data secara mendetail menggunakan media cetak seperti buku, jurnal, ataupun media informatika lainnya, semisal ebook, dan tulisantulisan sebelumnya sebagai tambahan sumber dalam teori penulisan. ${ }^{15}$ Data tersebut kemudian disatukan dengan proses Text Reading (dibaca), dipahami, dipelajari, dan dicatat sebagai sebuah informasi terkait problem

${ }^{10}$ Baca, Pendidikan Anti Kekerasan oleh, Rahmat, PAI Interdisipliner; Layanan khusus CIBI, Kenakalan Remaja, Integrasi IMTAQ \& IPTEK, Pendidikan Anti Kekerasan, dan Kurikulum Berbasis Karakter (Yogyakta: Deepublish Publisher, 2016), hlm.57-70.

${ }^{11}$ Sudarwan Danim, Menjadi Peneliti Kualitatif : Rancangan Metodologi, Presentasi, Dan Publikasi Hasil Penelitian Untuk Mahasiswa Dan Peneliti Pemula Bidang Ilmu-Ilmu Sosial, Pendidikan, Dan Humaniora, 1 (satu) (Bandung: PT. Remaja Rosdakarya, 2002), 51. 2000), hlm. 3 .

${ }^{12}$ Lexy J. Moleong, Metodologi Penelitian Kualitatif (Bandung: PT. Remaja Rosdakarya,

${ }^{13}$ Mahmud, Metode Penelitian Pendidikan (Bandung: Pustaka Setia, 2011), 31.

${ }^{14}$ Abdul Rahman Shaleh, Pendidikan Agama Islam Dan Pengembangan Untuk Bangsa (Jakarta: PT. Raja Grafindo Persada, 2005), 63.

${ }^{15}$ Abdurrahman Soejono, Metode Penelitian Suatu Pemikiran Dan Penerapan (Jakarta: Reneka Cipta, 1999), 25. 
yang sedang dikaji, sehingga dapat memberikan kemudhan dalam menyusun penulisan.

\section{Pembahasan}

\section{Model dan Komponen Pembelajaran Pendidikan Agama Islam Berlandaskan Multikultural}

Proses sosialisasi yang paling penting dan mendasar merupakan bagian penting dalam pengasuhan dan pendidikan anak. Sebab proses ini berperan penting dalam mempersiapkan anak menjadi anggota masyarakat yang baik. Anak memiliki banyak arti dan peran yang penting bagi keluarga. Anak dapat menjadi tumpuan harapan keluarga, dan anak dapat menjadi tempat bagi orang tua untuk mencurahkan segala perasaannya, baik perasaan senang maupun sedih. Lebih dari itu orang tua berharap agar anak dapat menjadi generasi penerus keluarga, khususnya orang tua. Dengan demikian, anak menjadi dambaan keluarga yang diharapkan dapat menjadi penerus cita-cita keluarga (Koentjoroningrat, 1989; 99).

a. Model Pembelajaran

Model pembelajaran tersusun atas dasar beberapa prinsip atau teori ilmiah. Para ahli membentuk model pembelajaran berasaskan prinsipprinsip pembelajaran, teori psikologi, sosiologi, penganalisisan sistem, atau teori-teori lainnya yang mendukung. Joyce \& Weil menganalisa model-model pembelajaran dengan memperhatikan teori belajar yang digolongkan menjadi empat model pembelajaran. Model itu ialah pola umum aktivitas pembelajaran guna menggapai tujuan pembelajaran yang telah direncanakan. Joyce \& Weil ${ }^{16}$ memberikan pendapat bahwa model pembelajaran yaitu suatu rancangan atau pola yang dipergunakan untuk merancang kurikulum (rencana pembelajaran jangka panjang), menentukan bahan-bahan pembelajaran, serta memberikan bimbingan pembelajaran di kelas dan lain sebagainya. model pembelajaran dapat dijadikan alternatif, maknanya para dosen boleh menentukan model pembelajaran yang relevan dan efisien untuk menempuh tujuan pendidikan.

b. Komponen Model Pembelajaran

Secara umum model dimaknai sebagai desain konseptual yang dipakai sebagai acuan dalam melaksanakan suatu kegiatan atau untuk mencapai tujuan tertentu di dalam sebuah satuan pendidikan. ${ }^{17}$

\footnotetext{
${ }^{16}$ Bruce Joyce \& Marsha Weil, Models of Teaching, Fifth Edition. (USA: Allyn And Bacon A Simon \& Scuster Company, 1980), hlm. 1.

${ }^{17}$ Abdul Majid, Strategi Pembelajaran, (Bandung: PT Remaja Rosdakarya, 2013), hlm. 13.
} 
1) Pendekatan

Setidaknya terdapat beberapa pendekatan dalam Pendidikan Agama Islam berwawasan multikultural:

2) Pendekatan Historis ${ }^{18}$

Pendekatan historis berkontribusi terhadap pendidikan dari evaluasi pengalaman sejarah berupa law dan budaya masyarakat. Sebuah sistem pendidikan tidak datang begitu saja, namun ia adalah mata rantai yang berkesinambungan dari cita-cita luhur dan praktik pendidikan pada masa sebelumnya baik yang tersirat maupu yang tersurat.

3) Pendekatan Sosiologis

Pendekatan sosiologis menginspirasi dalam terbentuknya kerangka budaya yang mana suatu pendidikan tentunya mengalami perkembangan, seperti mengganti, menentukan sampai mengembangkan budaya. Dimana pendidikan itu berbalik atau bergerak mulai dari kerangka kebudayaan yang telah ada baik mengganti menentukan dan memberikan pengembangan terhadap kebudayaan itu sendiri.

Sosiologi dimanfaatkan untuk mengerti tuntutan yang absah dari masyarakat (the legitimate demands of society). Kenyataannya sejauh ini sosiologi acapkali diartikan sebagai suatu kajian terhadap komunitas masyarakat serta isu-isu sosial terdahulu, sekarang, dan untuk masa yang mendatang. Didapati beberapa hal yang memang hasil telaah sosiologi yang mempunyai hubungan akan pendidikan. Adapun beberapa hal itu yakni: inovasi teknologi, struktural keluarga, inovasi masyarakat, kemajemukan kultur dan pluralis, dan nilai-nilai gaya kehidupan yang dinamis. ${ }^{19}$

4) Pendekatan Kultural

Pendekatan ini menekankan pada keaslian dan kebiasaan yang dikembangkan. Adanya pendekatan ini pembelajar dapat melihat manakah tradisi yang asli dan manakah yang sebaliknya. Secara otomatis juga pebelajar mampu untuk mengetahui dimana tradisi dari Arab dan yang mana sejatinya tradisi dari syariah atau Islam.

5) Pendekatan Psikologi

Yaitu pendekatan yang memeberikan pemahaman akan tabiat mahasiswa, para dosen, cara-cara termujarab dalam praktik,

18 https://andiplampang.wordpress.com/2010/12/09/metode-dan-pendekatan-pendidikanmultikultural/ diakses hari kamis 2 Agustus 2018 pukul 23:39 WIB.

${ }^{19}$ James A. Beane, et.all, Curricullum Planning and Development, (United Stete of America: McGraw-Hill Book Company, 1991), hlm. 90-98. 
mencapai dan menilai serta mengukur kemudian mengadakan bimbingan. Pendidikan yang berhasil dalam mencapai tujuannya, harus mempunyai informasi tentang tabiat mahasiswa, dosen, pengukuran dan evaluasi yang tepat dan baik.

Psikologis dipakai untuk menganalisa kemampuan awal mahasiswa dan yang menjadi kebutuhan mahasiswa (the ability and needs of children). Nana Syaodih Sukmadinata berpendapat, dasar Psikologi ini sangat penting untuk dimengerti Sebab dalam prosesnya terjadi hubungan erat antara individu manusia yakni antara mahasiswa kepada dosen dan juga antara mahasiswa dengan orang-orang sekelilingnya. Lebih dalam lagi, ia menegaskan bahwa kondisi psikologi masing-masing mahasiswa beragam, dikarenakan keragaman tahap perkembangan, latar belakang sosial budaya, serta keberbedaan faktor-faktor bawaan lahir. Olehkarenanya, menurut beliau, interaksi yang dibangun dalam keadaan pendidikan demikian harusnya disesuaikan dengan kondisi psikologi si mahasiswa maupun kondisi dosennya. Interaksi mahasiswa dengan dosen setingkat perguruan tinggi berbeda dengan jenjang sekolah dasar,menengah pertama dan menengah atas. ${ }^{20}$

6) Pendekatan Estetika

Pendekatan estetik secara mendasar menuntun mahasiswa untuk bersikap sopan santun, ramah tamah, dan mencintai kedamaian serta keindahan. Karena semua mata kuliah apabila berhenti pada pendekatan kognitif dan konsep-konsep kebenaran internal maka mahasiswa akan condong berperilaku kasar. Sehingga kelak mereka perlu diberikan pendekatan ini guna mendapatkan gambaran utuh terhadap semua gejala yang terjadi di masyarakat dan dengan mengetahuinya merupakan bagian dari serba-serbi kehidupan yang mengandung nilai seni maupun estetis.

7) Pendekatan Filosofis

Pendekatan filosofis berguna untuk mendapatkan pengetahuan akan keadaan alam semesta atau tempat tinggal (the kind of universe in which we live). Definisi umum, filsafat diartikan sebagai aktivitas berpikir dalam rangkaian menemukan hakikat dan hidup yang lebih bermakna. Di antara hasilnya dari pemikiran filsafat tersebut yaitu gagasan tentang hakikat manusia, nilai dan

${ }^{20}$ Nana Syaodih Sukmadinata, Pengembangan Kurikulum Teori dan Praktik, (Bandung: Rosda Karya, 2004) hlm. 45. 
sumbernya, berikut peranan serta tujuan pendidikan dalam menggapai kehidupan yang lebih menguntungkan (the good life). Dalam beberapa literatur, didapati 8 aliran filsafat yang berpola pemikiran tentang pendidikan, yaikni: idelalisme, realisme, pragmatisme, eksistensialisme, progresivisme, perenialisme, esensialisme, dan rekonstruksionisme. ${ }^{21}$

8) Adapun pendekatan dalam pembelajaran, dapat diklasifikasikan diantaranya, 1) Pendekatan Kontekstual, 2) Pendekatan Tematik.

9) Strategi

Secara kebahasaan, strategi dipahami sebagai siasah, cara-cara, trik atau kiat. Menurut istilah nya strategi adalah sebuah garis besar haluan dalam berperilaku untuk menggapai tujuan yang telah dicanangkan. ${ }^{22}$

Ada banyak strategi bagi perguruan tinggi dalam mengaplikasikan pendidikan agama Islam berlandaskan multikultural diantaranya,

a) Strategi pembelajaran berkelompok (cooperative learning) artinya kegiatan pembelajaran yang menitikberatkan kepada adanya perubahan skill mahasiswa pada aktivitas pembelajaran bersama guna internalisasi nilai-nilai dalam bungkus budaya daerah di dalam masing-masing kelompok belajar secara bersamaan dengan mempertimbangkan latar belakang kemajemukannya.

b) Strategi pencapaian konsep (concept attainment) yang dipakai dalam proses perkuliahan untuk memfasilitasi mahasiswa dalam menjalankan studi kearifan lokal dalam kelompok kerjanya.

c) Strategi analisis nilai (value analysis) tujuannya adalah mempertajam psikomotorik mahasiswa dalam penalaran, membangun daya konstruk dari ranah tanggapan dan pertanggungjawaban nilai-nilai kearifan lokal menuju desain dan struktur fisik tentang tatacara memandang lebih general pada sekup nasional atas asas sikap kebangsaan.

d) Strategi analisis sosial (social analysis) memiliki tujuan guna mendapatkan informasi tentang kejadian-kejadian dalam kehidupan bermasyarakat yang mempunyai budaya yang beragam, termasuk etnik, adat istiadat, dan agama, sehingga

21 Lihat, George R. Knight, Issues and Alternatives in Educational Philosophy, (Michigan: Andrews University Press, 1992), hlm. 35-107.

${ }^{22}$ Jurnal, M. Sobry, Reaktualisasi Strategi Pendidikan Islam: Ikhtiar Mengimbangi Pendidikan Global, (Jurnal Studi Keislaman: Ulumuna), Volume 17 No. 2 Desember 2013. 
mahasiswa dapat mengkaji banyak latar belakang tersebut saat menumbuhkembangkan pemahaman serta kesadaran akan keberadaan ragam kultural dalam masyarakat, sehingga bisa menimbulkan respon yang positif, yaitu sikap penghargaan, penghormatan terhadap kemajemukan budaya dalam kehiduapn masyarakat yang berbangsa, bernegara dan era 4.0 saat ini tentunya. ${ }^{23}$

Menurut HAR Tilaar, bangsa yang buta akan strategi dalam mengelolah kebudayaan bangsanya yang mana telah mendapatkan tantangan yang sedemikian dahsyat, sungguh menghawatirkan akan tergelincir terbawa derasnya arus sehingga kelak kehilangan identitas diri bangsanya. Pendidikan Multikultural seyogyanya dimanfaatkan sebagai strategi dalam merawat kebudayaan dengan tetap memberikan tawaran strategi transformasi budaya yang mumpuni yaitu melalui langkah-langkah pendidikan dengan orientasi menghargai sebuah perbedaan suatu budaya (different of culture).24

Ada 4 (empat) unsur yang mendasari penentuan atau pemilihan sebuah strategi pendidikan multikultural, yakni:

a) Mempertimbangkan kemudahan, kesiapan dan keunggulan sebuah strategi serta mempertimbangkan kebutuhan masyarakat setempat yang cenderung kebutuhannya bersifat dinamis.

b) Mempertimbangkan dan memilah pendekatan yang utama (basic way) dan paling memungkinkan untuk dilaksanakan agar menunjang dalam mencapai terget yang diinginkan

c) Mempertimbangkan dan memilih langkah sistematis (steps) yang akan dilalui mulai titik awal sampai titik akhir

d) Mempertimbangkan dan menentukan patokan (criteria) tolak ukur (standard) agar dapat mengukur dan memberi penilaian terhadap capaian keberhasilan (achievement) yang telah diusahakan.

Dari keempat macam pertimbangan tersebut, perlu ditambahkan di sini bahwa definisi strategi itu dipakai di dalam setiap konteks dan mempunyai arti yang tak selamanya sama. Di dalam hal penilaian misalnya, strategy dimaknai yaitu keseluruhan prosedur atau pola

${ }^{23}$ Jurnal Agus Munadlir, Strategi Sekolah dalam Pendidikan Mulitkultural, (Yogyakarta: Jurnal JPSD) Vol 2, No 2 Agustus 2016, hlm. 125.

${ }^{24}$ HAR Tilaar dalam Choirul Mahfud, Pendidikan Multikultural, (Yogyakarta: Pustaka Pelajar, 2010), hlm. 183. 
umum yang perlu ditempuh oleh pendidik dalam melakukan aktivitas penilaian hasil belajar efektif terhadap mahasiswa, guna mencapai tujuan yang telah ditentukan. ${ }^{25}$

10) Metode

Dalam istilah Arab, metode disebut thariqah ini berartikan jalan strategis dalam melakukan sebuah kegiatan. Metode pengajaran bisa dimaknai juga cara yang dipakai oleh dosen di dalam membuat mahasiswa belajar ketika pembelajaran berlangsung. Menurut Hasan Langgulung metode merupakan jalan atau cara yang mesti dilalui demi mencapai tujuan dalam pendidikan, sedangkan Ahmad Tafsir ${ }^{26}$ menjelaskan metode yaitu cara yang paling baik, cepat dan tepat dalam menyampaikan materi ajar. Adapun macam-macam metode ${ }^{27}$ diantaranya terdapat, 1) Metode ceramah, 2) Tanya jawab, 3) Diksusi, 4) Penugasan, 5) Demonstrasi, 6) Kerja kelompok, 7) Kayawisata, dll.

11) Teknik (Taktik)

Berbeda dengan metode, teknik lebih bersifat spesifik, teknik pada aplikasinya prktisnya diterapkan dalam kelas pembelajaran. Teknik yaitu cara yang kongkrit dan digunakan dalam proses belajar mengajar. Pendidik diperkenankan mengganti teknik mengajarnya walaupun metodenya sama. Dalam satu metode, dapat didukung dengan berbagai teknik pembelajaran. ${ }^{28}$

\section{Dialektika Landasan Multikultural di Indonesia}

a. Pendidikan Agama Islam Berlandaskan Multikultural

Ketika dianalisis lebih dalam, didapati pada kenyataannya bahwa Islam merupakan agama yang ramah dan menuntun umatnya untuk menghargai realitas keanekaragaman (sunnatullah). Sejalan dengan ini, kemudian dipertegas pada konsep rahmatan lil 'alamîn adalah pondasi kultural dalam ajaran Islam. Maka untuk melaksanakan misi kemanusiaanya itu, Islam mempunyai instrumen yakni menjadikan pendidikan sebagai garda terdepan, dikarenakan pendidikanlah yang diperlukan seluruh ummat manusia. ${ }^{29}$ Pendidikan diamanahi

25 Baca, Sulalah, Pendidikan Multikultural Didaktika Nilai-nilai Universalitas Kebangsaan, (Malang: UIN-Maliki Press, 2011), hlm. 126.

${ }_{26}$ Ahmad Tafsir, Metodologi Pengajaran Agama Islam, (Bandung: PT Remaja Rosdakarya, 1996), hlm. 9.

${ }^{27}$ Bahan Ajar, Milan Rianto, Pendekatan, Strategi, dan Metode Pembelajaran, (Malang: Pusat Pengembangan Penataran Guru, 2006), hlm. 47.

${ }^{28}$ Diktat perkuliahan Barkah Lestari dan Mustofa, Media Pembelajaran Mata Kuliah Perencanaan Pembelajaran, (Yogyakarta: Fak Ilmu Sosial, 2009), hlm. 1.

${ }^{29}$ Abudin Nata, Paradigma Pendidikan Islam (Jakarta: Grasindo, 2001), hlm. 100. 
tanggungjawab guna menunjukkan rasa kemanusiaan, karakter dan kepribadian yang mendukung terbentuknya kedamaian dalam masyarakat lewat transfer pengetahuan, wawasan, dan motivasi bagi generasi penerus.

Di samping itu, pendidikan tidak bisa bersentuhan dengan budaya, maka dari itu, kebudayaan dan peradaban yang maju (di mana masyarakat sejahtera, damai, produktif, dan cinta damai serta keindahan) pastinya mendapat dukungan dari sistem pendidikan yang baik. ${ }^{30}$ Namun, mendiskusikan pendidikan (agama) Islam pada modern ini kadangkala memunculkan kegundahan tersendiri dalam benak kita akan ketertinggalan, kemunduran, dan keadaan yang serba tidak menentu. Pendidikan Islam yang merupakan bagian dari system pendidikan nasional tersebut memiliki andil dalam menyebarkan paham nilai-nilai pluralis, multikultural, inklusiv serta toleransi.

Akan tetapi nyatanya, menurut Kautsar Azhari Noer, pendidikan agama Islam yang diajarkan baik di sekolah, madrasah, pesantren, perguruan tinggi dan institusi Islam yang lain turut berkontribusi ekslusivisme di dalam ajaranya. Hal itu menurutnya disebabkan oleh: Pertama, Pendidikan Islam lebih menekankan kepada proses penyampaian pengetahuan agama dari pada proses internalisasi nilainilai dan praktik agama atau dengan istilah lain, mahasiswa sekarang ahli ilmu agama bukan ahli praktik agama; Kedua, Anggapan terhadap pendidikan agama masih hanya sebatas "pemanis kurikulum" belaka maupun dianggapnya sebagai "pelengkap"; Ketiga, minimnya penekanan terhadap value akhlaq yang menuntut kepada saling menghormati antar agama, semisal nilai cinta, kasih sayang, persahabatan, tolong-menolong, cinta damai serta toleransi, dan; Keempat, kurang memperhatikan ajaran-ajaran yang bisa jadi baik dalam agama lain. ${ }^{31}$

Pada kesempatan lain Muhaimin menyatakan identifikasinya bahwa gagalnya pendidikan agama Islam penyebabnya yaitu, Pertama, pendidikan agama terlalu terpusat pada simbol-simbol agama, ritual, dan bersifat legal formal (halâl-harâm) serta hilangnya ruh moralitas; Kedua, pendidikan agama hanya bertumpukan pada penggemblengan ranah kognisi dan paling jauh hingga ranah emosi. Terkadang malah kebalikannya dengan hanya menggarap ranah emosi tanpa memberi perhatian pada ranah kognisi. Dampaknya, mahasiswa kurang mampu

\footnotetext{
${ }^{30}$ Abudin Nata, Paradigma Pendidikan Islam......, hlm. 138.

31 Rohani, Isu-isu kritis Pendidikan Kontemporer, Wawasan Multikultural Dalam Pendidikan Islam, (ISSN 1829-765X), hlm. 67.
} 
dalam ranah psikomotorik (praktik beragama),32 pada akhirnya banyak dijumpai pembicara agama yang bermunculan namun tidak sesuai dengan prilaku kesehariannya. ${ }^{33}$ Keadaan ini bagi Harun Nasution, akibat dari pendidikan agama kebanyakan dipengaruhi pola pikir Barat yang jelas hanya mengedepankan pengajaran ketimbang pendidikan karakter (Akhlaq). Padahal, intisari dari pendidikan agama Islam justru terletak padap pendidikan Akhlaqnya. ${ }^{34}$

Sementara itu, terdapatt juga banyaknya kelemahan yang lain, yakni: 1) Bidang teologi (ketauhîdan), ada indikasi yang cenderung mengarah kepada paham fatalistik; 2) Bidang akhlak (Akhlâq) hanya berorientasikan untuk urusan sopan dan santun serta tanpa memahaminya sebagai gambaran utuh dari pribadi manusia yang beragama; 3) Bidang ibadah ('ibadâh) didoktrinkan sebagai rutinitas beragama dan kurangnya penekanan sebagai suatu proses pembentukan kepribadian; 4) Bidang hukum (fiqh) condong diajarkan sebagai aturanaturan yang yang stagnan, dan tidak memahami maqashidu as-Syari'ah dan dinamikanya; 5) Agama Islam konsen diajarkan sebagai dogma dan kurangnya pengembangan rasionalitas terhadap kecintaan untuk memmajukan bidang keilmuan Islam; 6) Berorientasi mempelajari alQur'an untuk sekedar mengasah kemampuan membaca teks yang tersurat, dan belum mengarah kepada pemahaman makna dan penggalian kandungan Al-Qur'an itu sendiri yang tersirat.

Fenomena yang komplit ini, setidaknya ada 2 hal yang dapat diupayakan; Pertama, Islam dipelajari sebagai niatan untuk menjadi hamba dan ummat yang benar dalam menjalankan agama yang dianutnya; Kedua, Pelajarilah Islam tidak hanya untuk pengetahuan. Dalam bahasa lain, belajar agama merupakan sebagai usaha membentuk sikap beragama yang bertekat komitmen, loyal dan berdedikasi tinggi, yang sekaligus juga mampu memposisikan diri sebagai pelajar, peneliti dan pengabdi yang kritis guna meningkatkan dan mengembangkan keilmuan. ${ }^{35}$

b. Nilai-nilai dan Indikator Pendidikan Multikultural

\footnotetext{
${ }^{32}$ Muhaimin, Arah Pengembangan Pendidikan Islam: Pemberdayaan, Pengembangan Kurikulum, hingga Redefinisi Islamisasi Ilmu Pengetahuan, (Bandung: Nuansa, 2003), hlm. 71.

33 Sumartana, dkk., Pluralisme, Konflik dan Pendidikan Agama di Indonesia, (Yogyakarta: Pustaka Pelajar, 2001), hlm. 239-240.

${ }^{34}$ Harun Nasuiton, Islam Rasional: Gagasan Pemikiran, (Bandung: Mizan, 1995), hlm. 425 .

35 Komaruddin Hidayat, "Memetakan Kembali Struktur Keilmuan Islam (Kata Pengantar)", dalam Fuaduddin dan Cik Hasan Bisri, Dinamika Pemikiran Islam di Perguruan Tinggi: Wacana tentang Pendidikan Agama Islam, (Jakarta: Logos, 1999), hlm. xii-xiii.
} 
Sedangkan pembahasan terhadap nilai-nilai di dalam multikultural Abdullah Aly berpendapat terdapat keselarasan antara nilai-nilai multikultural menurut Barat dan menurut ajaran Islam. Akan tetapi, walaupun demikian, kebenaran nilai-nilai Barat bersumber dari filsafat yang mementingkan hak-hak asasi kemanusiaan, adapun nilai-nilai multikultural dalam Islam bersumberkan wahyu ilahiah ${ }^{36}$ Pembagian atau klasifikasi perspektif nilai tersebut dijelaskan pada tabel berikut:

Tabel 1 Nilai dan Karakteristik Multikultural

\begin{tabular}{|c|c|c|c|}
\hline No & Karakteristik & $\begin{array}{c}\text { Nilai } \\
\text { Multikultural } \\
\text { Perspektif } \\
\text { Barat }\end{array}$ & $\begin{array}{c}\text { Nilai } \\
\text { Multikultural } \\
\text { Perspektif } \\
\text { Islam }\end{array}$ \\
\hline 1 & $\begin{array}{l}\text { Berprinsip pada } \\
\text { demokrasi, kesetaraan, } \\
\text { dan keadilan }\end{array}$ & $\begin{array}{l}\text { Demokrasi, } \\
\text { kesetaraan dan } \\
\text { keadilan }\end{array}$ & $\begin{array}{l}\text { Al-Musyawarah } \\
\text { dan al-'adl }\end{array}$ \\
\hline 2 & $\begin{array}{l}\text { Kesetaraan, keadilan } \\
\text { dan demokrasi }\end{array}$ & $\begin{array}{l}\text { Kebersamaan, } \\
\text { kedamaian dan } \\
\text { kemanusiaan } \\
\end{array}$ & $\begin{array}{l}\text { Hablum min al- } \\
\text { nas, dan as- } \\
\text { salam }\end{array}$ \\
\hline 3 & $\begin{array}{l}\text { Mengembangkan sikap } \\
\text { mengakui, menerima } \\
\text { dan menghargai } \\
\text { keragaman. }\end{array}$ & $\begin{array}{l}\text { Toleransi, } \\
\text { empati, } \\
\text { simpati, dan } \\
\text { solidaritas } \\
\text { sosial }\end{array}$ & $\begin{array}{l}\text { Al-ta'adudyat, } \\
\text { al-tanawwu'al- } \\
\text { tasamuh, al- } \\
\text { 'afw, dan al- } \\
\text { ihsan. }\end{array}$ \\
\hline
\end{tabular}

c. Prinsip-prinsip Pendidikan Agama Islam Berlandaskan Multikultural

Adapun dalam prinsipnya, pendidikan multikultural Tilaar memberikan pendapat, Pertama, pendidikan multikultural berlandaskan pada pedagogik kesamaan manusia (equity pedagogy), Kedua, pendidikan multikultural diperuntukkan kepada perwujudan manusia Indonesia yang memiliki kecerdasan dan pengembangan kepribadian bangsa yang mempunyai ilmu pengetahuan yang baik dan luas, Ketiga, prinsip global tidak perlu diwaspadai berlebihan jika bangsa ini memahami arah dan dapat memilah mana nilai baik maupun buruk yang terdapat di dalamnya. ${ }^{37}$

Ketiga prinsip menurut Tilaar di atas, tentang pendidikan multikultural tersebut cukup memberi gambaran bahwasanya arah dari landasan multikultural yaitu untuk mewujudkan manusia yang terbuka akan segala macam dinamika kehidupan zaman serta keberagaman berbagai bidang didalam kehidupan modern.

${ }^{36}$ Abdullah Aly, Pendidikan Islam Multikultural Di Pesantren, (Yogyakarta: Pustaka Pelajar, 2011), hlm. 124.

${ }^{37}$ H.A.R. Tilaar, Multikulturalisme; Tantangan-tantangan Global Masa Depan Dalam Transformasi Pendidikan Nasional, (Jakarta: Grasindo, 2004), hlm. 195. 


\section{Model Pembelajaran Pendidikan Agama Islam Berlandaskan Multikultural di Perguruan Tinggi}

Menurut Rusman, ${ }^{38}$ model pembelajaran Pendidikan Agama Islam (PAI) berlandaskan multikultural di perguruan tinggi memiliki beberapa ciri yang peneliti rangkum menjadi 5 (lima) kriteria yakni sebagaimana berikut:

a. Berlandaskan ketentuan teori pendidikan dan teori belajar dari para pemerhati pendidikan. Contohnya, model penelitian kelompok yang digagas oleh Herbert Thelen dan berdasarkan teorinya John Dewey. Model semacam ini didesain guna melatih keikutsertaan dalam kelompok secara demokratis.

Dari ciri model pembelajaran pertama ini, menurut peneliti efektifnya dosen dapat memilih dan menggunakan model pembelajaran PAI dari teori atau pendapt para ahli yang telah familiar dimanfaatkan dalam pembelajaran sebut saja model pembelajaran kooperatif learning. Sebagaimana diketahui, model pembelajaran kooperatif learning ini mengarahkan kepada pembelajaran bersama-pembelajaran dengan ketergantungan positif ${ }^{39}$ dan aktivitas pembelajaran yang demikian sangat cocok bagi Bangsa Timur yakni Indonesia yang memiliki falsafat gotong royong-berat sama dipikul, ringan sama dijinjing.

b. Mempunyai misi atau tujuan pendidikan tertentu, misalnya model berpikir induktif dirancang untuk mengembangkan proses berpikir induktif.

Pada ciri kedua ini, menyambung dari apa yang telah dibahas pada ciri pertama. Sehingga, dengan model pembelajaran kooperatif tersebut sesuai dengan misi dan tujuan seorang dosen yang ingin menitik beratkan pada landasan multikultural dalam pembelajaran.

c. Dapat dijadikan pedoman untuk perbaikan kegiatan belajar mengajar di kelas, misalnya model Synectic dirancang untuk memperbaiki kreativitas dalam penulisan makalah.

Namun demikian, dalam ciri ketiga ini dosen juga dituntut untuk tidak hanya pembelajaran bersama akan tetapi seharusnya pembelajaran dapat terus dimonitoring agar mahasiswa dapat belajar aktif (Active learning) sesuai dengan harapan yakni pembelajaran bersama yang menghasilkan perbaikan dan peningkatan terhadap kualitas daya kreativitas mahasiswa dalam penulisan dan presentasi. 2, hlm. 136.

${ }^{38}$ Rusman, Model-model Pembelajaran, (Jakarta: PT RajaGrafindo Persada, 2010), Cet-

39 Baca, Barkah Lestari, Peningkatan Kualitas Pembelajaran Dengan Model Pembelajaran Cooperative Learning, Jurnal Ekonomi \& Pendidikan, Volume 5 Nomor 2, Desember 2008, hlm. 145-152. 
d. Memiliki bagian-bagian model yang dinamakan: (1) Urutan langkahlangkah pembelajaran (Syntax); (2) Adanya prinsip-prinsip reaksi; (3) Sistem sosial; dan (4) Sistem pendukung. Keempat bagian tersebut merupakan pedoman praktis bila dosen akan melaksanakan suatu model pembelajaran.

Selanjutnya, dosen menentukan pembelajaran yang sistematis kemudian melaksanakan langkah-langkah pembelajaran yang telah dirancangnya tersebut. Sebab, dalam sebuah model minimal memiliki beberapa komponen, (1) Pendekatan (pendekatan kooperatif); (2) Strategi. Strategi yang dapat digunakan adalah strategi perencanaa, pelaksanaan, Pelaksanaan observasi atau pemantauan, dan Refleksi; ${ }^{40}$ (3) Metode. Metode yang dapat digunkan adalan metode pembelajaran Jigsaw; ${ }^{41}$ dan (4) Teknik. Adapun teknik yang dapat dimanfaatkan adalah teknik ceramah, diskusi dan penugasan.

e. Memiliki dampak sebagai akibat terapan model pembelajaran. Dampak tersebut meliputi: (1) Dampak pembelajaran, yaitu hasil belajar yang dapat diukur; (2) Dampak pengiring, yaitu hasil belajar jangka panjang.

Pada akhirnya, ciri kelima yaitu model pembelajaran yang dimanfaatkan itu harus diyakini oleh seorang dosen dapat memberikan dampak terhadap perbaikan sikap penghormatan, penerimaan dan penghargaan terhadap keniscayaan multikultural.

\section{Kesimpulan}

Dari uraian di atas, peneliti simpulkan bahwa Pembelajaran pada hakikatnya merupakan suatu proses interaksi antara dosen dengan mahasiswa, baik interaksi secara langsung seperti kegiatan tatap muka maupun secara tidak langsung, yaitu dengan menggunakan berbagai media baik cetak (buku) maupun digital (online). Model pembelajaran adalah suatu rencana atau pola yang dapat digunakan untuk membentuk kurikulum (rencana pembelajaran jangka panjang), merancang bahanbahan pembelajaran, dan membimbing perkuliahan atau yang lain.

Adapun model pembelajaran yang dapat dimanfaatkan dalam pembelajaran Pendidikan Agama Islam berlandaskan multikultural adalah model pembelajaran Cooperative Learning sehingga mahasiswa dapat mengaplikasikan pembelajaran berkelompok namun tidak hanya

${ }^{40}$ Baca, Harli Trisdiono, dkk, Strategi Implementasi Model Pembelajaran Kooperatif Tipe Jigsaw, Jurnal Pendidikan dan Pembelajaran, 7 (2) 95-103, Desember 2017. ISSN: 25285173.

${ }^{41}$ Bandingkan dengan, Bahan Ajar, Milan Rianto, Pendekatan, Strategi, dan Metode Pembelajaran, (Malang: Pusat Pengembangan Penataran Guru, 2006), hlm. 47. 
berimplikasi terhadap aktivitas bekerjasama, lebih dari itu masing-masing personal mahasiswa harus dapat juga secara aktif memahami pokok masalah dan bahasan tugas kelompok mereka sehingga harapan dari model pembelajaran kooperatif yaitu ketergantuan positif dapat terwujud, sebab jika tidak demikian maka hanya akan menghasilkan pemebelajaran yang membebani bagi mahasiswa lain. Apabila hal tersebut terjadi maka suatu kelompok yang tergabung dalam penyelesaian tugas tersebut malah hanya akan menimbulkan prasangka bahkan pengucilan terhadap individu lain yang dirasa hanya membebankan tugasnya pada anggota kelompok dan ia dianggap tidak memiliki kepedulian terhadap tugasnya sebagai anggota kelompok yang seharusnya saling ketergantungan positif yaitu saling memberi keuntungan dalam menyelesaikan sebuah tugas.

\section{Daftar Rujukan}

Alim, Muhammad, Pendidikan Agama Islam Upaya Pembentukan Pemikiran dan Kepribadian Muslim Bandung : PT.Remaja Rosda Karya, 2006

Aly, Abdullah, Pendidikan Islam Multikultural Di Pesantren, Yogyakarta: Pustaka Pelajar, 2011

Assegaf, Abd. Rachman, "Kata Pengantar" dalam Syamsul Kurniawan, Pendidikan di Mata Soekarno; Modernisasi Pendidikan Islam dalam Pemikiran Soekarno, Yogyakarta: Ar-Ruzz Media Group, 2009

Bruce Joyce \& Marsha Weil, Models of Teaching, Fifth Edition. (USA: Allyn And Bacon A Simon \& Scuster Company, 1980

Darajat, Zakiah, Pendidikan Islam dalam Keluarga dan Sekoalh, Bandung: Remaja Rosdakarya, 1995

Dawam, Ainurrafiq, "Emoh Sekolah": Menolak "Komersialisasi Pendidikan" dan "Kanibalisme Intelektual", Menuju Pendidikan Multikultural, Jogjakarta: INSPEAL Ahimsakarya Press, 2003

Fahrurrozi, "Nilai-nilai Hak Asasi Manusia dalam Buku Ajar Pendidikan Agama Islam di Sekolah Menengah Atas Daerah Istimewa Yogyakarta," Jurnal Studi Agama Millah, Vol. IV, No. 2 Januari 2005

George R. Knight, Issues and Alternatives in Educational Philosophy, Michigan: Andrews University Press, 1992

Harli Trisdiono, dkk, Strategi Implementasi Model Pembelajaran Kooperatif Tipe Jigsaw, Jurnal Pendidikan dan Pembelajaran, 7 (2) 95-103, Desember 2017. ISSN: 2528-5173

Hidayat, Komaruddin, "Memetakan Kembali Struktur Keilmuan Islam (Kata Pengantar)", dalam Fuaduddin dan Cik Hasan Bisri, Dinamika Pemikiran Islam di Perguruan Tinggi: Wacana tentang Pendidikan Agama Islam, Jakarta: Logos, 1999 
HS Barrows, RM Tamblyn, Problem-Based Learning, An Approach to Medical Education. Adult Educ Quart, 2002; 43 (4)

https://andiplampang.wordpress.com diakses pada tanggal 23 September 2019, pukul 07:30 WIB

https://www.liputan6.com diakses diakses 19 Agustus 2019. Pukul 16.13 WIB.

Imam Setyobudi dan Mukhals Alkaf, Kendala Multikulturalisme di Indonesia Analisis Diakronis dan Sinkronis, (Mudra Jurnal Seni Budaya) ISSN 08543461, Vol 26, No2 Juli 2011

Jalaluddin, Teologi Pendidikan, Jakarta: RajaGrafindo, 2003

James A. Banks and Cherry A. McGee Banks, Handbook of Research on Multicultural Education, San Francisco, California: Jossey-Bass, 1996

James A. Beane, et.all, Curricullum Planning and Development, United Stete of America: McGraw-Hill Book Company, 1991

Lestari, Barkah dan Mustofa, Media Pembelajaran Mata Kuliah Perencanaan Pembelajaran, Yogyakarta: Fak Ilmu Sosial, 2009

Mahfud, Choirul, Pendidikan Multikultural, Yogyakarta: Pustaka Pelajar, 2010

Majid, Abdul, Strategi Pembelajaran, Bandung: PT Remaja Rosdakarya, 2013

Muhaimin, Arah Pengembangan Pendidikan Islam: Pemberdayaan, Pengembangan Kurikulum, hingga Redefinisi Islamisasi Ilmu Pengetahuan, Bandung: Nuansa, 2003

Munadlir, Agus, Strategi Sekolah dalam Pendidikan Mulitkultural, Yogyakarta: Jurnal JPSD) Vol 2, No 2 Agustus 2016

Nasuiton, Harun, Islam Rasional: Gagasan Pemikiran, Bandung: Mizan, 1995

Nata, Abudin, Paradigma Pendidikan Islam Jakarta: Grasindo, 2001

Parekh, Bikhu, Rethinking Multiculturalisme: Keberagaman Budaya dan Teori Politik, Yogyakarta: Kanisius, 2008, cet. Ke-5

Rahmat, PAI Interdisipliner; Layanan khusus CIBI, Kenakalan Remaja, Integrasi IMTAQ \& IPTEK, Pendidikan Anti Kekerasan, dan Kurikulum Berbasis Karakter Yogyakta: Deepublish Publisher, 2016

Rianto, Milan, Pendekatan, Strategi, dan Metode Pembelajaran, Malang: Pusat Pengembangan Penataran Guru, 2006

RM Felder, R Brent, Effective Strategies for Cooperative Learning. J Coop Collab Teaching, 2001; 10 (2)

Rohani, Isu-isu kritis Pendidikan Kontemporer, Wawasan Multikultural Dalam Pendidikan Islam, ISSN 1829-765X

Rusman, Model-model Pembelajaran, Jakarta: PT RajaGrafindo Persada, 2010, Cet-2 
S. Truna, Dody, Pendidikan Agama Islam Berwawasan Multikulturalisme, Telaah Kritis atas Muatan Pendidikan Multikulturalisme dalam Buku Ajar Pendidikan Agama Islam (PAI) di Perguruan Tinggi Umum di Indonesia Jakarta: Kementerian Agama RI, 2010

Sobry, M., Reaktualisasi Strategi Pendidikan Islam: Ikhtiar Mengimbangi Pendidikan Global, (Jurnal Studi Keislaman: Ulumuna), Volume 17 No. 2 Desember 2013

Sulalah, Pendidikan Multikultural Didaktika Nilai-nilai Universalitas Kebangsaan, Malang: UIN-Maliki Press, 2011

Sulalah, Pendidikan Multikultural Didaktika Nilai-nilai Universalitas Kebangsaan, Malang: UIN-Maliki Press, 2011

Sumartana, dkk., Pluralisme, Konflik dan Pendidikan Agama di Indonesia, Yogyakarta: Pustaka Pelajar, 2001

Suryadinata dkk, Penduduk Indonesia, Jakarta: LP3ES, 2003

Syaodih Sukmadinata, Nana, Pengembangan Kurikulum Teori dan Praktik, Bandung: Rosda Karya, 2004

Tafsir, Ahmad, Metodologi Pengajaran Agama Islam, Bandung: PT Remaja Rosdakarya, 1996

Tilaar, H.A.R., Multikulturalisme; Tantangan-tantangan Global Masa Depan Dalam Transformasi Pendidikan Nasional, Jakarta: Grasindo, 2004

Yakin, M. Ainul, Pendidikan Multikultural; Cross-Kultur Understanding untuk Demokrasi dan Keadilan, Yogyakarta: Pilar Media, 2005

Yaqin, Ainul, Pendidikan Multikultural: Cross Cultural Understanding untuk Demokrasi dan Keadilan, Yogyakarta: Pilar Media, 2005

Yaya Suryana, H. A. Rusdiana, Pendidikan Multikultural Suatu Upaya Penguatan Jati Diri Bangsa, "Konsep-Prinsip-Implementasi", Bandung: Pustaka Setia, 2015 